\title{
University Civic Engagement in Bangladesh and Potential Alternative Pedagogies
}

\author{
Meghna Guhathakurta \\ Research Initiatives, Bangladesh (RIB), Banani, Dhaka - 1213, Bangladesh \\ Corresponding author. E-mail: meghna.guhathakurta@gmail.com \\ https://doi.org/10.12982/CMUJASR.2017.0002
}

$\prod_{\text {his study examined the history and potential of university civic }}^{\text {ABSTRACT }}$ engagement in Bangladesh. Post-colonial models of civic engagement of universities contested earlier models of alienation between universities and surrounding communities. Such trends were located in western academia, as well as embedded in the thinking of the East, e.g., Randindranath Tagore's community of practice embodied in Sriniketan, a college which inspired and assisted community initiatives in Bangladesh and South Asia. Bangladesh has undergone tremendous changes since its independence in 1971. The role of public universities has been prominent in the reconstruction of the nation and hence the relationship between the community and academia has been close and engaged. But this has been more apparent in political and civic discourses and social movements, rather than in curriculum content and structure. While a few exemplars of university civic engagement in Bangladesh exist, they are mostly initiatives of innovative teachers and institutions; no systemic attempt has been made to incorporate civic engagement into the university curricula in Bangladesh. Thus, while the legacy and terrain for civic engagement is rich in Bangladesh, the number of programs is few, mostly due to lack of funding and time constraints inherent in the semester system. There is, however, potential for alternative pedagogies to evolve. Appropriate institutional linkages and intellectual endeavor are needed to support and channel this trend into effective civic engagement practices.

Keywords: Civic engagement, Universities, Bangladesh 


\section{INTRODUCTION}

Historically, a notable number of universities emerged as centers of high intellectual achievement, often in opposition to the local community in which they were situated. This divide has been referred to as 'townies' versus 'gownies'. The universities of Oxford and Cambridge in the United Kingdom are two of the oldest that epitomize this model. This alienation between universities and their surrounding communities spread to other educational institutions in both colonial and post-colonial societies, as well as post-industrial Western democracies. In colonial British India, Rabindranath Tagore, a Nobel Prize winner in literature, tried to rectify this divide through his concept of rural reconstruction as embodied in his inception of Palli Samgathana Vibhaga (PSV, or Rural Development Department) at Sriniketan in 1922 (later integrated into the curriculum of Viswa Bharati University, Bolpur, India), with the objective of implementing extension programs and supporting activities in more than two dozen nearby villages (Ghosh \& Chattopadhyay, 2000).

Civic engagement was popularized in the USA in the 1960s with the advent of College Work Study, the Peace Corps, and Volunteers in Service to America (VISTA). The term came to mean individual and collective actions designed to identify and address issues of public concern that ranged from individual voluntarism to organizational involvement to electoral participation, and included efforts to directly address issues, work with others in a community to solve problems, or interact with the institutions of representative democracy. Civic engagement promoted quality of life in a community, through both political and non-political processes.

The role of higher education and universities in promoting civic engagement is justified by the need to have more socially responsible knowledge that encourages young people to be good citizens and contribute to their communities. An ideal program of university civic engagement would aim to build a long-term mutually beneficial partnership between the university and its local community. It would explore how a university could make its resources available to the local community in ways that were equally beneficial to local groups and to the university's core aims of teaching and research.

At the turn of the millennium, Robert Putnam, in a groundbreaking book "Bowling Alone: The Collapse and Revival of American Community" (Putnam, 2000), showed how contemporary society had become increasingly disconnected from family, friends, neighbors, and democratic structures - in short, how social capital, the very fabric of networks, norms, and social trust that facilitate coordination and cooperation for mutual benefit, has plummeted, impoverishing lives and communities. He also suggested how connections could be reestablished. These ideas hinged on the notion of what we call civic engagement and civic learning. 


\section{RELATED CONCEPTS, NOTIONS, AND PROGRAMS OF CIVIC ENGAGEMENT}

Civic engagement has been defined as:

working to make a difference in the civic life of one's community and developing the combination of knowledge, skills, values and motivation to make that difference. It means promoting the quality of life in a community, through both political and non-political processes (Erlich, 2000, vi).

An associated term is Civic Learning and Democratic Engagement (CLDE), which means promoting the education of students for engaged citizenship through democratic participation in their communities, respect and appreciation of diversity, applied learning, and social responsibility.

A common denominator of the above terms is knowledge and learning, which is inevitable given the role of universities in producing knowledge and learning. First, universities apply their knowledge to help build strong vibrant communities in the neighborhood, helping to bridge the divide between the two. Second, civic engagement generates specific knowledge that becomes a core learning outcome for students themselves.

Civic engagement is also broadly understood as community engagement, which is defined as the collaboration of higher institutions and their larger communities (local, regional, national, global) for the mutually beneficial exchange of knowledge and resources in the context of partnership and reciprocity (Bowen, 2010). This creates an extended connotation that lies in the terms 'mutually beneficial exchange of knowledge' and in the hint of 'partnership and reciprocity'. It is expected that students and faculties have much to learn from communities themselves and internalize, institutionalize, and integrate such learning into the university curriculum (Bowen, 2010). This latter trend is more evident in the knowledge practices, like participatory action research, and also in the thinking behind Tagore's establishment of Sriniketan, which will be part of the later discussion.

The trends mentioned here have given rise to various programs of different genres in educational institutions all over the world. Civic engagement can take many forms, but mostly they are conceived in contradistinction with electoral and political voice. Civic engagement includes community problem solving, regular volunteering for a non-electoral organization, active membership in a group or association, and even symbolic non-participation. They sometimes overlap with activities of electoral and political engagement, but not necessarily so. These activities may consist of engaging citizens to vote or giving support to deprived communities for them to develop a political voice.

Civic engagement has flourished in the western world in university programs since the beginning of the $21^{\text {st }}$ century. Glen Bowen (2010) has written a resource and reference manual 
"Civic Engagement in Higher Education" that lists major websites and sources. Community-university partnership programs have been greatly enriched and enhanced by the pedagogic influence of participatory action research principles. For example, Community University Partnership (Cupp) at the University of Brighton, UK established three aims that were closely related to concepts of communities of practice (Millican \& Wolf, 2014):

- To ensure the university's resources (intellectual and physical) are made available and informed by and used by the local and subregional communities;

- To enhance the capacity of community and university for engagement for mutual benefit; and

- To ensure that Cupp resources are prioritized to address inequalities between the university and local communities.

These main principles were also seen in the trends of learning attached to powerful front-runners of thought and practice about the community in the nonwestern world. For example. Paulo Freire and Orlando Fal Borda in Latin America, the philosophy of President Julius K. Nyerere of Tanzania influencing a community of researchers in the University of Dar es Salaam, and Rabindranath Tagore in India through his seat of learning in Viswa Bharati, popularly known as Shantiniketan, and the Institute of Rural Reconstruction at Sriniketan.
Rabindranath's thoughts influenced not only Bengal, but also South Asia, if not the world. Hence, in a discussion of community practices in Bangladesh, it is imperative that one reflects on the thoughts of Rabindranath (Ghosh, \& Chattopadhya, 2000; Rahman, 2006):

- To win the friendship and affection of the villagers and the cultivators by taking real interest in all that concerns their life and welfare and by making a lively effort to assist them in solving their most pressing problems;

- To take the problems of the village and field to the classroom for study and to the experimental farm for solutions;

- To carry the knowledge and experience gained in the classroom and the experimental farm to the villagers, in the endeavors to improve their sanitation and health; to develop their resources and credit; to help them sell their produce and buy their requirements to the best advantage; to teach them better methods of growing crops and vegetables and keeping livestock; to encourage them to learn and practice arts and crafts; and to bring home to them the benefits of community life, mutual aid and common endeavor;

- To work out practically an all-round system of elementary education in the villages, based on the Boy Scout ideal and training, with the objects of developing citizenship and public duty such as 
may appeal to the villagers and be within their means and capacity; and

- To encourage the staff and students of the department itself to instill a spirit of sincere service and sacrifice in the interest of, and on terms of comradeship with their poorer, less educated and greatly harassed neighbors in villages" (Ghosh \& Chattopadhay, 2000).

Sriniketan inspired and assisted community initiatives in many villages, including clearing jungles to create farms, planting vegetable gardens, building roads, and experimenting with cooperative farming and collective paddy stores (Rahman, 2006). The strength of Tagore's concept of Atma-Shaktiand Shakti-Samavay (selfreliance and cooperative strength as the means of rural development) inspired generations in India, Pakistan, and Bangladesh, especially during times of great political and social transformations, such as the birth of Bangladesh in 1971.

\section{THE EMERGENCE OF BANGLADESH}

The end of the British colonial period in 1947 left the South Asian sub-continent divided, based on religion, into two nation-states - India and Pakistan. The Islamic Republic of Pakistan was in turn divided into East and West, separated by thousands of miles of India, thus creating a geographical and cultural dilemma. While East Bengal, which was named
East Pakistan, was more populous than West Pakistan, West Pakistan tried to impose Urdu as the state language on the entire country. Students at the University of Dhaka, in the capital of East Pakistan, were the first to protest; this developed into a student-led resistance, the Bengali Language Movement, of 1952, in which many students gave their lives. Protests expanded into many spheres until independence was achieved in 1971 at the cost of millions of lives.

\section{Education in Bangladesh}

The main education system in Bangladesh is divided into three levels: primary, secondary, and tertiary. At all levels of schooling, students can choose to receive their education in English or Bangla. Private schools tend to use of English-based study media, while government-sponsored schools use Bangla. Tertiary education in Bangladesh takes place at government, private, and international universities; these include universities and colleges in specialized fields, such as agriculture, engineering, and medicine.

\section{The role of universities in reconstruc- tion of a nation}

Reconstruction followed independence, with the building of a new nation-state whose infrastructure had been totally devastated by the war. Many students who had joined the war for independence as young guerillas answered Bangabandhu Sheikh Mujibur Rahman's call for nation-building. The newspapers were full of stories of such ventures, many of which were 
documented by Anisur Rahman in his seminal book "JeyAgunJolechhilo: muktijuddher chetonar shotosfurto prokash (The Fire that Burned: a spontaneous expression of the spirit of the Liberation War)" (Rahman, 2000). Rahman, who at the time was teaching at the University of Dhaka, also wrote about how he and other faculty members accompanied their students in this engagement with community, state, and society. He outlined some of the values that inspired the students in this journey and many of these values carried the legacy of Tagore's philosophy, including:

- Dignity and self-reliance, from which people did not depend on others but used their own resources and labor;

- Cooperative and collective work was better than individuals competing against each other;

- Respect for physical labor and to resort to such labor for the benefit of society without any hesitation;

- To bridge the gap between the middle-class and the common people by working together for the common good of the state and society;

- Encourage students and teachers to engage themselves with the community alongside their studies; and

- To eradicate illiteracy from society and take this as a social movement (Rahman, 2000).

The above principles were not imposed on students and the young, but were meant to develop their creativity.

\section{TYPES OF UNIVERSITY CIVIC ENGAGEMENT}

Since independence, universities, both public and private, have proliferated to meet the demands of a growing young population. NGOs also have also established universities, some of high repute, like BRAC (Lewis, 2017). In response to students increasingly concerned about joining the work force, universities began emphasizing more profession-based subjects, such as law, business studies, computers, and development studies, and increasingly embedded service learning into the curricula, although the semester system constrained the time available for such activities. More recently, university departments have introduced threemonth long internship courses (for which students are graded) which have allowed students to be placed in work settings linked to their subject, through which they gain experience and hands on training.

Some departments, through teacher and student initiative, have developed innovative programs that engage students in community outreach. These generally fall within the lines of civic engagement as discussed in this article. Two such examples (personal communication with faculty members) are mentioned here:

Empowerment through the Law of the Common People (ELCOP) is a voluntary program affiliated closely with the Faculty of Law at the University of Dhaka that embraces communities for democracy, justice, and empowerment through action and participation. Its objectives are to: 
- Provide people with specific legal information, making them conscious of their rights and duties;

- Improve understanding of basic norms and values underlying democracy in the society;

- Foster justice, tolerance, fairness, and transparency in society;

- Contribute to lifting and empowering the marginalized sections of society;

- Involve the students and teachers of law in promoting legal awareness to help institutionalize democracy

ELCOP is administered and managed by law students and teachers from many universities across Bangladesh, and includes outside legal experts in its activities.

ELCOP's programs have included Community Legal Research, which documents the legal problems of minorities and the deprived and builds local capacity by identifying and training potential community leaders. Another program was derived from ELCOP's Street Law curriculum; translated in Bangla as Protidiner Ain (Law of Daily Life Struggles), it raises awareness about human rights, democratic norms, rights and duties, and other legal issues people face in their daily life. Each year, Protidiner Ain aims to train about 1500 secondary and higher secondary students, 30 opinion leaders, 100 slum dwellers, and 100 workers in the formal and informal sectors.

Another example of civic engagement can be taken from the NGO-based
BRAC University. Its James P. Grant School of Public Health serves as the secretariat for a civil initiative called Bangladesh Health Watch (BHW), a multi-stakeholder, civil society, advocacy and monitoring network dedicated to improving the health system in Bangladesh through critical review of policies and programs and recommendation of appropriate actions for change. It publishes an annual report on the state of health in Bangladesh every year by commissioning research. Various donors, including SIDA and the Rockefeller Foundation, fund BHW.

Universities, whether public or private, face resource constraints of both time and money in trying to accommodate civic engagement programs in their curricula. This often limits them to providing service-learning courses that provide hands on training for their students, albeit within the parameters of conventional pedagogies.

\section{ALTERNATIVE PEDAGOGIES AND INSTITUTIONS}

Research Initiatives, Bangladesh (RIB) was founded to promote knowledge on poverty alleviation that was relevant, useful, innovative, participatory, and action-oriented (Guhathakurta, 2014). RIB conducts people's research (gonogobeshona) on development schemes that affect the community to develop ownership and generate community mobilization. RIB is run by a board of eminent individuals of high academic repute that includes Anisur Rahman, renowned action researcher and interpreter of Tagore's philosophy. The 
legacy of Tagore and action research was, therefore, etched in the research agenda of RIB from the start.

But taking this agenda forward in the contemporary setting of Bangladesh was not an easy task. RIB was supported by an innovative Dutch research program entitled Multi-annual Multi-disciplinary Research Program (MMRP) that allowed southern researchers to define their own agendas of research.

At first, reaching out to university faculties was difficult, as teachers were too busy with their own research or consultancies. RIB board members, therefore, decided to reach out to students (identified by their teachers who then played a supervisory role) by funding field research for term papers related to poverty-alleviation. During field work, some students wanted to learn more about participatory action research. In response, RIB held a five-day residential workshop on the topic. Students were excited about the process, because (a) they were exposed to a different culture than the one they were used to seeing: marginal, religious and ethnic minorities, rural; (b) they learnt through the very process that they came to learn, i.e., the workshop itself was designed on the principles of action research, as opposed to classroom lectures; and (c) stereotypes, such as poor people could not think for themselves, were broken down. One participant commented on observing how villagers managed their own paddy stock and distributed them from a common 'bank' during times of famine,
I am amazed at how efficiently and effectively they take decisions through their meetings; compared to them if you look at how our ministers meet to discuss matters of national importance, they are not half so effective and yet more costly in terms of resources.

Communities also benefitted from this interaction with students. One person from the Dalit outcaste community who worked as a sweeper at the University of Rajshahi was amazed when some of the participants returning from the PAR workshop treated him with respect and asked about is welfare every morning when he swept the floors of their classrooms.

Although these programs did not have an immediate effect on university curricula, they did influence departments to open up their curricula to service-learning courses (Mohsin, et al., 2016).

These courses also enriched the CVs of participants, helping in their search for employment. In fact, after the service-learning courses were offered in the Department of International Relations at the University of Dhaka, RIB received many requests for placements at both the undergraduate and graduate levels.

RIB further cooperated with university students in fields other than action research. They collaborated with the Goethe Institute of Dhaka and Kolkata and the Centre for Studies in the Social Sciences in Kolkata and the University of Heidelberg to conduct a 
joint project called "Inherited Memories", a third-generation perspective of the 1947 Partition. Students from East and West Bengal gathered stories from their grandparents who had migrated during the 1947 division of the sub-continent into India and Pakistan, with special reference to Bengal and the impact that it had on their lives. There were also significant implications for the communities they studied. Through the project, two participants, one each from West Bengal and Bangladesh, revisited their old village/ residence in their 'home' country for the first time in over 60 years, an emotional sojourn. But more important for Bangladesh was that the Inherited Memories project unearthed a forgotten history for many communities.

\section{CONCLUSION}

While the legacy and terrain for community engagement of universities in Bangladesh is a rich one, the number of such programs is few, due to lack of funding and the time constraints inherent in the semester system. But as the examples in this article revealed, some faculties that have demonstrated a flexible approach and thought outside of the box have succeeded in building collaborative relations with like-minded institutions and introduced servicelearning components in their curricula.

Unlike the past colonial era of the divide between the 'townies' and 'gownies' Universities in Bangladesh are deeply embedded in the social history and relations of their surroundings. What remains to be done is to support and channelize this trend into effective engagement practices that can nourish both community and institution in the days to come.

\section{REFERENCES}

Bowen, G. (2010). Civic engagement in higher education, resources and references. West Carolina University: Center for Service Learning.

Erlich, T. (2000). Civic responsibility and higher education. American Council on Education, New York: Oryx Press.

Ghosh, M., \& Chattopadhya, B. (2000). Development as empowerment: $A$ report on the study on the grassroot level governance as mandated in the $73^{\text {rd }}$ ammendment of the constitution with reference to the idea of rural reconstruction envisaged by Rabindranath, Sriniketan. Career Publications.

Lewis, D. (2017). Organising and representing the poor in a clientilistic democracy: the decline of radical NGOs in Bangladesh. Journal of Development Studies, 53(10), 1545-1567. https://doi.org/10.10 80/00220388.2017.1279732

Millican, J., \& Wolff, D. (2014). Community-University partnership programme. In Coghlan, D., \& Miller, M.B. (Eds.), The Sage Encyclopedia of Action Research, Vol. 1 (pp. 150-152). London: Sage Reference.

Mohsin, A., Hossain, D., \& Ashraf, A. (2016). Self-assessment report, Department of International Relations. Dhaka: University of Dhaka. 
Putnam, R. (2000). Bowling alone: The collapse and revival of American Community. New York: Simon \& Schuster.

Rahman, A. (2000). Jey Agun Jolechilo: Muktijuddher Chetonar Shotosfurto Prokash (The Fire that Burned: a spontaneous expression of the spirit of the Liberation War). Dhaka: Gonoprokashoni
Rahman, A. (2006). Roots of action research and self-reliance thinking in Rabindranath Tagore. Action Research Journal, 4(9), 231-245. https://doi.org/10.1177/14767 50306063994 